\title{
Expectations: Leadership, Dialogue and Continuing Commitment to Diversity Promotion
}

\author{
Beverlee Kissick Ph.D. and Saeed Khan Ph.D. \\ Kansas State University at Salina
}

Introduction:

An individual's growth is linked to the growth of the society to which she or he belongs. As our society becomes increasingly diverse the success of each person becomes increasingly intertwined with the growth of the whole society. The following quote from George Land's Grow or Die [1] attests to this interdependence of the individual and the collective,

"In a multicellular relationship or in a cultural group, cell and Man respond in a like manner, not only extending the self, but performing acts and making products that facilitate the growth of the organism as a whole."

For several years we have been concerned with understanding diversity, teaching diversity and developing diversity skills [2]. Even those who understand the great benefits of diversity and passionately promote it will accede to the difficulty of moving forward with diversity issues. The complexities of diversity become apparent through the differences among people. These differences include visible components such as food, clothing, language and physical features; and invisible components like values, beliefs, attitudes, perceptions, assumptions and communication styles. These latter and more subtle dimensions can be described as hidden or submerged. In order for one to truly appreciate diversity, one needs to probe deeply into the submerged portion as well as the overt. What follows is an attempt to classify promotional efforts, and to assess the coverage of diversity issues by these efforts.

In a previous effort to categorize diversity promotion activities at the College of Technology and Aviation (COTA) of Kansas State University (K-State), Kissick and Khan [3] resorted to a system of classification that addressed four different levels of concern. The areas of concern identified were as follows: (1) personal level (how do I feel about those who are different?); (2) interpersonal level (how do I behave with regard to people who are different?); (3) institutional and organizational level (what are the politics, treatment, behavior, procedures, and policies toward different groups of people?); and (4) cultural or societal level (how do we broaden our view of what is right and good?) [4]. The goal of this first classification was to study the effectiveness of the 
COTA programs in responding to the diversity needs of the college and it was concluded that a fair amount of attention was given to all four areas listed above.

This paper uses a second classification system that relies on a list of multicultural competencies [5] developed by the Tilford Group (a group charged with developing a multicultural curriculum model at K-State) to evaluate COTA programming. While a more detailed description is presented in a later section, the competencies have three broad areas: (1) Knowledge (awareness and understanding needed to live and work in a diverse world); (2) Personal Attributes (traits needed by those who live and work in a diverse world); (3) Skills (behavior and performance tasks needed to live and work in a diverse world). This second classification is important for the following reasons:

- Examines the compliance of COTA efforts with the multicultural competencies developed at K-State by the Tilford Group.

- Studies comparatively, the compliance of COTA efforts using both systems of classification.

- Comments on the relative merits and the desirability of each system.

Definition of Terms:

In this paper diversity is defined as:

the recognition and celebration of the differences that exist in our society.

Diversity is about acknowledging and tolerating our differences, even when those differences may make us uncomfortable. Diversity is about recognizing these barriers that unfairly restrict access to our social system, and prevents us from building a broader community infrastructure [4]. The words diversity and multiculturalism are interchangeable for the purposes of this paper.

Cultural competence is defined as:

a set of congruent behaviors, attitudes, and policies that coalesce in a system or agency, or among a group of professionals, that enables that system, agency or group to work effectively in multicultural situations. Cultural competence is not a tonic or product that can be dispensed at a workshop or noted on a certificate.

Cultural competence is a set of skills or perspectives that require lifelong learning and a disciplined effort continues to try on new and often uncomfortable behavior [4].

A diversity event is defined as:

any activity related to the recognition and celebration of diversity. In this paper an event is distinguished from a program (defined below) by the fact that it is not a prescribed activity. As an example, special discussions, dances, and lunches are being defined as events because they are not intended to form a part of a series. However, this does not mean that theses events cannot mutate into programs once the decision is made to regularize them.

Diversity programs are defined as:

a series of events (as defined above) sharing a common theme or style of delivery.

Diversity initiatives are defined as:

steps taken in the attempt to bring about positive and lasting changes that benefit the diversity environment. Because of their overall impact, initiatives are more fundamental than diversity events and programs. 
Events, Programs and Initiatives taken at COTA:

Before the level of compliance of our promotional activities can be judged, a brief introduction to our events, programs and initiatives must be provided. All activities are presented in a tabular form (Table IA-IC) for convenient perusal. In addition to providing a name for the occurrence, the first column tells whether it is a singular event, or a part of a program or an initiative. These three tables include most if not all of the promotional efforts that have taken place over the last 2-3 years.

\begin{tabular}{|c|c|c|c|}
\hline \multicolumn{4}{|c|}{$\begin{array}{c}\text { TABLE 1-A } \\
\text { DIVERSITY EVENT, PROGRAMS AND INITIATIVES LIST }\end{array}$} \\
\hline Name/Type & Facilitator & Description & Benefits/Purpose \\
\hline $\begin{array}{l}\text { Diversity Counts } \\
\text { Campaign } \\
\text { EVENT } \\
\end{array}$ & $\begin{array}{l}\text { Multicultural } \\
\text { Connection } \\
\text { Committee (MCC) }\end{array}$ & $\begin{array}{l}\text { College wide } \\
\text { promotional event }\end{array}$ & $\begin{array}{l}\text { Environmental } \\
\text { Impacts }\end{array}$ \\
\hline $\begin{array}{l}\text { Tell me your story } \\
\text { PROGRAM }\end{array}$ & $\begin{array}{l}\text { MCC } \\
\text { College Dean } \\
\text { Students }\end{array}$ & $\begin{array}{l}\text { Periodic panel } \\
\text { discussions on cultural } \\
\text { diversity of students } \\
\text { and faculty who form } \\
\text { panel members }\end{array}$ & $\begin{array}{l}\text { Multicultural } \\
\text { education }\end{array}$ \\
\hline $\begin{array}{l}\text { Religions of the world } \\
\text { EVENT }\end{array}$ & $\begin{array}{l}\text { MCC } \\
\text { Faculty }\end{array}$ & $\begin{array}{l}\text { A diverse group of } \\
\text { faculty discuss their } \\
\text { faith }\end{array}$ & $\begin{array}{l}\text { Multicultural } \\
\text { education focusing on } \\
\text { religious differences }\end{array}$ \\
\hline $\begin{array}{l}\text { Sponsored speakers } \\
\text { PROGRAM }\end{array}$ & $\begin{array}{l}\text { Joseph Onijala, } \\
\text { Workforce Diversity } \\
\text { Manager for Boeing }\end{array}$ & $\begin{array}{l}\text { Diversity dimensions } \\
\text { at Boeing }\end{array}$ & $\begin{array}{l}\text { Real world importance } \\
\text { of diversity }\end{array}$ \\
\hline $\begin{array}{l}\text { Sponsored speakers } \\
\text { PROGRAM }\end{array}$ & $\begin{array}{l}\text { Prof. Marcelo Sabates } \\
\text { Head of Philosophy, } \\
\text { K-State. }\end{array}$ & $\begin{array}{l}\text { Hispanic recruitment } \\
\text { and the state of } \\
\text { diversity at KSU }\end{array}$ & $\begin{array}{l}\text { Addresses the needs } \\
\text { and importance } \\
\text { recruitment efforts for } \\
\text { under-represented } \\
\text { students }\end{array}$ \\
\hline $\begin{array}{l}\text { Cultures of the world } \\
\text { PROGRAM }\end{array}$ & $\begin{array}{l}\text { Interested COTA } \\
\text { faculty and staff }\end{array}$ & $\begin{array}{l}\text { Library display cases } \\
\text { were used to exhibit } \\
\text { cultural displays }\end{array}$ & $\begin{array}{l}\text { Multicultural } \\
\text { education }\end{array}$ \\
\hline $\begin{array}{l}\text { International Tasting } \\
\text { Fair } \\
\text { PROGRAM }\end{array}$ & Faculty, staff, students & $\begin{array}{l}\text { Volunteers prepare } \\
\text { foods of diverse } \\
\text { cultures, share recipes } \\
\text { and personal } \\
\text { significance }\end{array}$ & $\begin{array}{l}\text { A taste of different } \\
\text { cultures and a } \\
\text { platform for } \\
\text { discussion of cultural } \\
\text { issues }\end{array}$ \\
\hline $\begin{array}{l}\text { Meetings with Tilford } \\
\text { Group } \\
\text { PROGRAM }\end{array}$ & $\begin{array}{l}\text { MCC members and } \\
\text { Chair }\end{array}$ & $\begin{array}{l}\text { Coordination with the } \\
\text { K-State body for the } \\
\text { development of a } \\
\text { multicultural } \\
\text { curriculum model }\end{array}$ & $\begin{array}{l}\text { Exchange of ideas } \\
\text { within the group and } \\
\text { input from other } \\
\text { colleges and } \\
\text { organizations in the } \\
\text { K-State system }\end{array}$ \\
\hline
\end{tabular}




\begin{tabular}{|c|c|c|c|}
\hline \multicolumn{4}{|c|}{$\begin{array}{r}\text { TABLE 1-B } \\
\text { DIVERSITY EVENT, PROGRAMS A }\end{array}$} \\
\hline Name/Type & Facilitator & Description & Benefits/Purpose \\
\hline $\begin{array}{l}\text { Great Ocean Voyager } \\
\text { Around the World } \\
\text { EVENT }\end{array}$ & Student presentation & $\begin{array}{l}\text { Student presentation } \\
\text { of his semester at sea } \\
\text { while traveling around } \\
\text { the world }\end{array}$ & $\begin{array}{l}\text { Excellent first hand } \\
\text { format for relating } \\
\text { cultural experiences }\end{array}$ \\
\hline $\begin{array}{l}\text { Who I am makes a } \\
\text { difference week } \\
\text { EVENT }\end{array}$ & $\begin{array}{l}\text { Laury } \\
\text { Kuder(admissions } \\
\text { rep.) and MCC }\end{array}$ & $\begin{array}{l}\text { College community } \\
\text { members pick up } \\
\text { "difference ribbons", } \\
\text { passing it to people } \\
\text { who make a difference } \\
\text { for them }\end{array}$ & $\begin{array}{l}\text { This was a celebration } \\
\text { of people of all } \\
\text { cultures within the } \\
\text { college community }\end{array}$ \\
\hline $\begin{array}{l}\text { Sponsored speakers } \\
\text { PROGRAM }\end{array}$ & $\begin{array}{l}\text { Dr. Marwa is the } \\
\text { founder, chairman and } \\
\text { CEO of Albarka } \\
\text { Airlines, Nigeria }\end{array}$ & $\begin{array}{l}\text { Operation of a } \\
\text { Nigerian airline }\end{array}$ & $\begin{array}{l}\text { International } \\
\text { perspective of the } \\
\text { airline industry for } \\
\text { aviation students. }\end{array}$ \\
\hline $\begin{array}{l}\text { Cuban and Costa } \\
\text { Rican dance troupe } \\
\text { EVENT }\end{array}$ & $\begin{array}{l}\text { Dance troupe and } \\
\text { MCC }\end{array}$ & Dance presentation & $\begin{array}{l}\text { Celebration of cultures } \\
\text { through the fine arts }\end{array}$ \\
\hline $\begin{array}{l}\text { Creation of a } \\
\text { discussion group for } \\
\text { promoting diversity in } \\
\text { the science and } \\
\text { technology classroom } \\
\text { INITIATIVE }\end{array}$ & $\begin{array}{l}\text { Faculty members Dr. } \\
\text { Beverlee Kissick, Dr. } \\
\text { Judy Collins, Dr. } \\
\text { Saeed Khan, Mike } \\
\text { Wilson and Pedro } \\
\text { Leite }\end{array}$ & $\begin{array}{l}\text { Brainstorming session } \\
\text { for developing the } \\
\text { mechanics of teaching } \\
\text { diversity through } \\
\text { science and } \\
\text { technology }\end{array}$ & $\begin{array}{l}\text { Bringing the real } \\
\text { world concerns into } \\
\text { science and } \\
\text { technology through } \\
\text { related diversity issues }\end{array}$ \\
\hline $\begin{array}{l}\text { St. Patrick's day } \\
\text { Luncheon } \\
\text { EVENT }\end{array}$ & Faculty and Staff & $\begin{array}{l}\text { Celebration of an Irish } \\
\text { holiday }\end{array}$ & $\begin{array}{l}\text { An attempt to show } \\
\text { that all individuals } \\
\text { belong to a cultural } \\
\text { group and } \\
\text { multiculturalism is } \\
\text { just a celebration of } \\
\text { this }\end{array}$ \\
\hline $\begin{array}{l}\text { Minority Student } \\
\text { Reception } \\
\text { EVENT }\end{array}$ & Faculty and Staff & $\begin{array}{l}\text { All minority students } \\
\text { invited to attend } \\
\text { gathering to foster } \\
\text { better relationships } \\
\text { with faculty/staff }\end{array}$ & $\begin{array}{l}\text { Celebrating minority } \\
\text { students help create } \\
\text { supportive } \\
\text { environment } \\
\text { necessary for retention }\end{array}$ \\
\hline $\begin{array}{l}m \& m \text { project } \\
\text { EVENT }\end{array}$ & $\begin{array}{l}\text { Laury Kuder } \\
\text { (admissions rep.) and } \\
\text { MCC }\end{array}$ & $\begin{array}{l}\text { Colorful m\&ms } \\
\text { distributed with MCC } \\
\text { programs }\end{array}$ & $\begin{array}{l}\text { Another celebration of } \\
\text { diversity }\end{array}$ \\
\hline
\end{tabular}




\begin{tabular}{|c|c|c|c|}
\hline \multicolumn{4}{|c|}{$\begin{array}{c}\text { TABLE 1-C } \\
\text { DIVERSITY EVENT, PROGRAMS AND INITIATIVES LIST }\end{array}$} \\
\hline Name/Type & Facilitator & Description & Benefits/Purpose \\
\hline $\begin{array}{l}\text { MCC meetings with } \\
\text { student government } \\
\text { members } \\
\text { INITIATIVE }\end{array}$ & $\begin{array}{l}\text { Student members of } \\
\text { MCC }\end{array}$ & $\begin{array}{l}\text { Seeking student } \\
\text { support in } \\
\text { multicultural } \\
\text { promotions }\end{array}$ & $\begin{array}{l}\text { Soliciting valuable } \\
\text { feedback from } \\
\text { students regarding } \\
\text { multicultural issues }\end{array}$ \\
\hline $\begin{array}{l}\text { Writing grants for } \\
\text { scholarship money for } \\
\text { under-represented } \\
\text { student groups } \\
\text { INITIATIVE }\end{array}$ & Faculty & $\begin{array}{l}\text { Grant proposals to aid } \\
\text { under-represented } \\
\text { students in science } \\
\text { and technology }\end{array}$ & $\begin{array}{l}\text { Intended to increase } \\
\text { the recruitment of } \\
\text { minority students }\end{array}$ \\
\hline $\begin{array}{l}\text { Cinco-de-Mayo } \\
\text { Luncheon } \\
\text { EVENT }\end{array}$ & Faculty and Staff & $\begin{array}{l}\text { Celebration of the } \\
\text { Mexican } \\
\text { Independence day }\end{array}$ & $\begin{array}{l}\text { Celebration of the } \\
\text { Mexican peoples }\end{array}$ \\
\hline $\begin{array}{l}\text { Multicultural Movie } \\
\text { Series } \\
\text { (Several showings } \\
\text { each year) } \\
\text { PROGRAM }\end{array}$ & Faculty & $\begin{array}{l}\text { Experts facilitate } \\
\text { discussions and } \\
\text { introduce movies } \\
\text { areas that speak to } \\
\text { their area of expertise }\end{array}$ & $\begin{array}{l}\text { Multicultural } \\
\text { education }\end{array}$ \\
\hline $\begin{array}{l}\text { Partnership with } \\
\text { Tuskegee University } \\
\text { PROGRAM }\end{array}$ & $\begin{array}{l}\text { Aviation Department } \\
\text { of COTA }\end{array}$ & $\begin{array}{l}\text { Program to train HBC } \\
\text { pilots at COTA }\end{array}$ & $\begin{array}{l}\text { A win, win situation } \\
\text { that improves and } \\
\text { adds to the number } \\
\text { minority students at } \\
\text { COTA while at the } \\
\text { same time providing } \\
\text { Tuskegee U. with pilot } \\
\text { training facilities }\end{array}$ \\
\hline $\begin{array}{l}\text { Multicultural Person } \\
\text { of the Year Award } \\
\text { PROGRAM }\end{array}$ & Awarded by MCC & $\begin{array}{l}\text { Encourages diversity } \\
\text { promoters on campus }\end{array}$ & $\begin{array}{l}\text { This award is a } \\
\text { recognition of the high } \\
\text { importance given to } \\
\text { diversity at COTA }\end{array}$ \\
\hline $\begin{array}{l}\text { Library Grant Money } \\
\text { PROGRAM }\end{array}$ & Dr. Beverlee Kissick & $\begin{array}{l}\text { Grant money was used } \\
\text { to purchase } \\
\text { multicultural } \\
\text { publications }\end{array}$ & $\begin{array}{l}\text { Multicultural } \\
\text { education }\end{array}$ \\
\hline $\begin{array}{l}\text { TWIST career day } \\
\text { PROGRAM }\end{array}$ & Students and Faculty & $\begin{array}{l}\text { Young women explore } \\
\text { science and } \\
\text { technology }\end{array}$ & $\begin{array}{l}\text { Encourages women to } \\
\text { engage in non- } \\
\text { traditional careers }\end{array}$ \\
\hline $\begin{array}{l}\text { Attending Presidents } \\
\text { Council of } \\
\text { Multicultural Affair } \\
\text { Meetings } \\
\text { PROGRAM } \\
\end{array}$ & MCC Chair & $\begin{array}{l}\text { Coordinating with the } \\
\text { umbrella organization } \\
\text { for diversity } \\
\text { promotion at K-State }\end{array}$ & $\begin{array}{l}\text { Coordinate, exchange } \\
\text { ideas and assist in } \\
\text { activities and } \\
\text { initiatives }\end{array}$ \\
\hline
\end{tabular}


Compliance between COTA activities and Four Levels of Concern:

While COTA activities have been previously studied for compliance with the first system of classification (four levels), it is being presented in tabular for convenience. This table (Table 2) lists only the events and programs and initiatives in each category and relies on tables $1 \mathrm{~A}-1 \mathrm{C}$ for descriptions. It should be remembered that many of these activities have benefits in more than one area, however, they are categorized under their primary function. A quick look at table shows that the coverage of diversity topics was quite evenly covered in every concerned area. While only two items are listed in the societal and cultural column, it should be noted that there were many different events in this area as well.

\section{Compliance between COTA activities and Tilford Competencies:}

In Table 3 we explore the coverage of the Tilford broad areas by COTA activities. In 2001, Tilford Group compiled a synthesis of multicultural competencies. They have defined multicultural competencies as knowledge, skills and personal attributes college graduates need to live in a diverse world.

I. "Knowledge----Awareness and understanding needed to live and work in a diverse world.

Cultural Self---The ability to understand one's ethnic identity and how it influences identity development.

Diverse Ethnic Groups---Knowledge of diverse ethnic groups and their cultures.

Social/Political Frameworks---Awareness of how economic, social and political issues impact race and ethnic relations.

Changing Demographics---Understanding population dynamics related to ethnic minority and majority citizens.

II. Personal Attributes---Traits needed by those who live and work in a diverse world.

Flexibility ---The ability to respond and adapt to new and changing situations.

Respect ---An appreciation for those who are different from one's self.

Empathy ---The ability to understand another person's culture by listening to and understanding their perspective.

III. Skills ---Behaviors and performance tasks needed to live and work in a diverse world.

Cross Cultural Communication --- Verbal and nonverbal communication skills in interaction with those who are culturally different from one's self. Teamwork ---The ability to work in culturally diverse groups toward a common goal.

Listening --- The ability to attend to what others are saying.

Conflict Resolution ---The ability to resolve cultural conflicts that occur between individuals and groups.

Critical Thinking --- The ability to use inductive and deductive reasoning. 
Language Development --- The ability to speak and write more than one language.

Leadership Development --- The ability to provide multicultural leadership." [4]

As can be seen from Table 3, there is also a good level of compliance of COTA activities with the Tilford competencies. While there are fewer items in the skill area, a lot of work has gone into setting up the discussion group for promoting diversity in the science and technology classroom. There are several teachers from diverse backgrounds at COTA that have chosen to get involved in this discussion group. It is believed that skills like cross cultural communication and teamwork are already getting a good amount of attention.

\begin{tabular}{|c|c|c|c|}
\hline \multicolumn{4}{|c|}{$\begin{array}{c}\text { TABLE } 2 \\
\text { COMPLIANCE OF COTA EFFORTS WITH THE FOUR LEVELS OF CONCERN } \\
\text { Please see tables } 1 \mathrm{~A}, 1 B \text { and } 1 C \text { for descriptions of events, programs and initiatives. } \\
\text { Items listed only under their primary function }\end{array}$} \\
\hline Personal Level & Interpersonal Level & Cultural and Societal & $\begin{array}{l}\text { Institutional and } \\
\text { Organizational Level }\end{array}$ \\
\hline 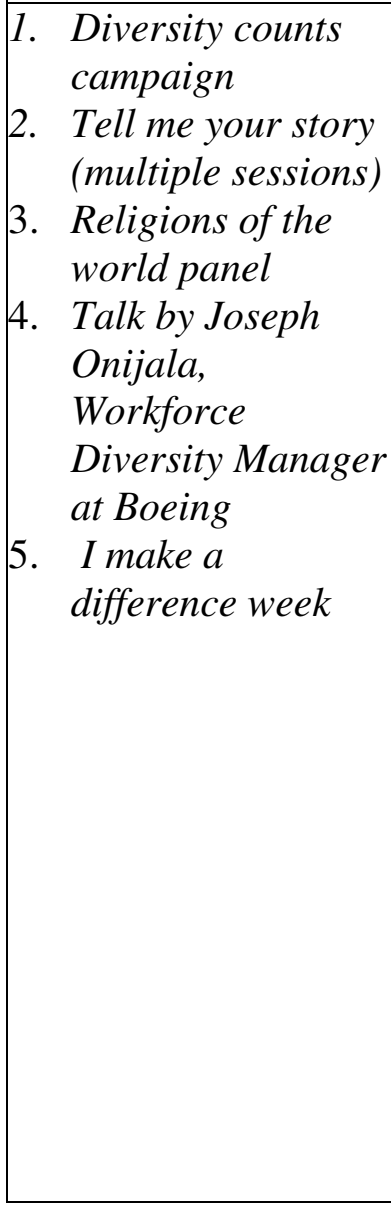 & 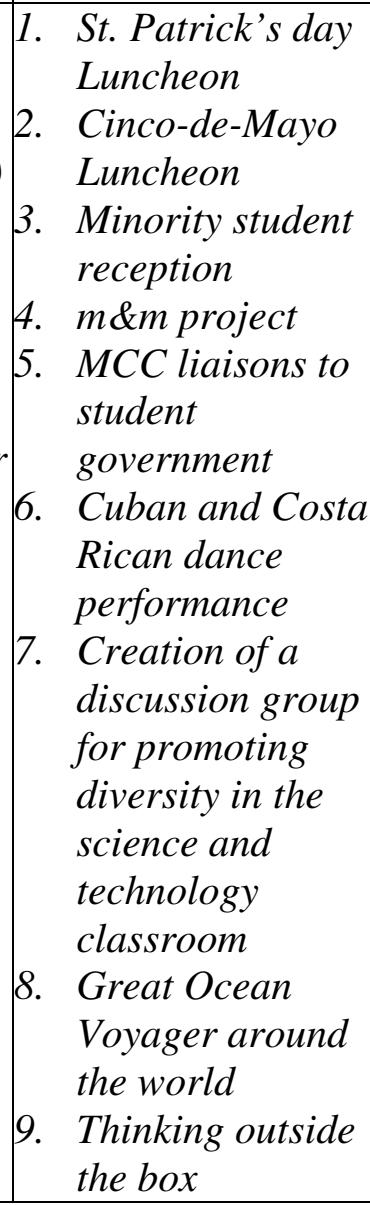 & $\begin{array}{l}\text { 1. Writing grants for } \\
\text { scholarship money } \\
\text { for under- } \\
\text { represented } \\
\text { student groups } \\
\text { 2. Multicultural } \\
\text { Movie Series, } \\
\text { some movies } \\
\text { introduced and } \\
\text { discussed include } \\
\text { Amistad, The } \\
\text { Battle for Algiers, } \\
\text { Ran, My Son the } \\
\text { Fanatic etc.; more } \\
\text { than } 15 \text { movies } \\
\text { featured thus far }\end{array}$ & 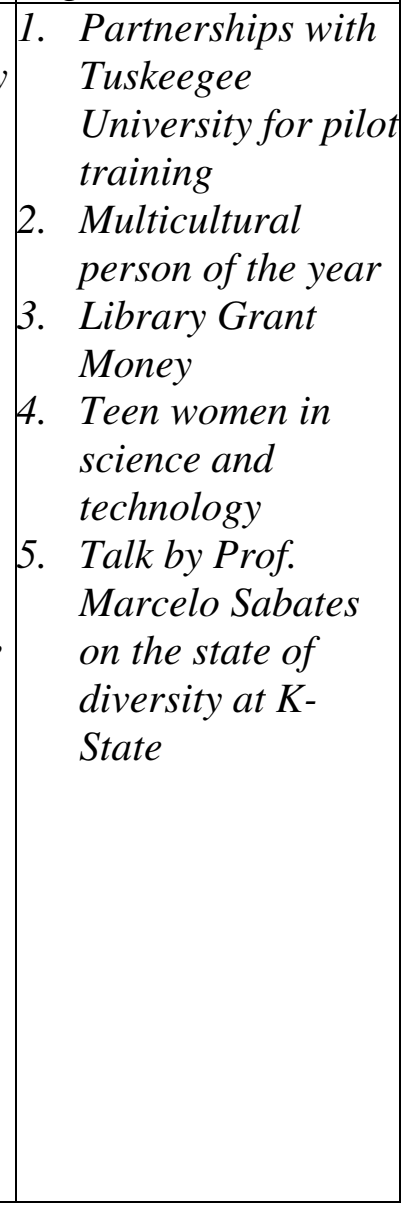 \\
\hline
\end{tabular}




\begin{tabular}{|c|c|c|}
\hline \multicolumn{3}{|c|}{$\begin{array}{c}\text { TABLE } 3 \\
\text { COMPLIANCE OF COTA EFFORTS WITH TILFORD COMPETENCIES } \\
\text { Please see tables } 1 A, 1 B \text { and } 1 C \text { for descriptions of events, programs and initiatives. } \\
\text { Items listed only under their primary function }\end{array}$} \\
\hline Knowledge & Personal Attributes & Skills \\
\hline $\begin{array}{l}\text { 1. I make a difference week } \\
\text { 2. Multicultural Movie } \\
\text { Series }\end{array}$ & $\begin{array}{l}\text { 1. St. Patrick's day } \\
\text { Luncheon } \\
\text { 2. Cinco-de-Mayo Luncheon }\end{array}$ & $\begin{array}{l}\text { 1. Creation of a discussion } \\
\text { group for promoting } \\
\text { diversity in the science } \\
\text { and technology classroom }\end{array}$ \\
\hline $\begin{array}{l}\text { 3. Talk by Prof. Marcelo } \\
\text { Sabates on the state of } \\
\text { diversity at } K \text {-State }\end{array}$ & $\begin{array}{l}\text { 3. } \text { Minority student reception } \\
\text { 4. } m \& m \text { project }\end{array}$ & $\begin{array}{l}\text { 2. Partnerships with } \\
\text { Tuskeegee University for } \\
\text { pilot training }\end{array}$ \\
\hline $\begin{array}{l}\text { 4. Tell me your story } \\
\text { (multiple sessions) }\end{array}$ & $\begin{array}{l}\text { 5. Diversity counts campaign } \\
\text { 6. Multicultural person of }\end{array}$ & $\begin{array}{l}\text { Writing grants for } \\
\text { scholarship money for } \\
\text { under-represented student }\end{array}$ \\
\hline $\begin{array}{l}\text { 5. Religions of the world } \\
\text { panel }\end{array}$ & the year & groups \\
\hline $\begin{array}{l}\text { 6. Cuban and Costa Rican } \\
\text { dance performance }\end{array}$ & $\begin{array}{l}\text { 7. Tell me your story } \\
\text { (multiple sessions) }\end{array}$ & \\
\hline $\begin{array}{l}\text { 7. Talk by Joseph Onijala, } \\
\text { Workforce Diversity } \\
\text { Manager at Boeing }\end{array}$ & $\begin{array}{l}\text { 8. Teen women in science } \\
\text { and technology }\end{array}$ & \\
\hline
\end{tabular}

Conclusion:

Nearly all the events, programs and initiatives in diversity promotion (for the last 2-3 years) have been surveyed and classified using two different systems of classification. In the first of the two systems all activities have been organized using four levels of concern [4]. By examining COTA efforts using the above system, it was found that the efforts have led to a fairly balanced coverage of issues. A second system of classification (Tilford Competencies) also resulted in fairly good coverage in the categories of interest. Conclusions can be drawn from the above results:

I. COTA efforts have provided widespread coverage in both systems of classification.

II. From the first deduction, it may further be concluded that both systems of classification are fairly comprehensive. If this was not the case, then 18 out of 21 activities could not have been categorized under both systems.

III. If the first two conclusions are accepted, then it may be said, that either system of classification can be successfully used. 
References:

1. Land, G., "Grow or Die: The Unifying Principle of Transformation", John Wiley and Sons, 1997, pp.816

2. Saeed Khan, "Teaching Diversity at the College of Aviation and Technology," Conference

Proceeding of the $33^{\text {rd }}$ ASEE/IEEE Frontiers in Education Conference, November 5-8, 2003, Boulder, CO, pages F3D-24 to F3D-28

3. Beverlee Kissick and Saeed Khan, "Expectations: Leadership, Dialogue and a Long-Term Commitment to diversity promotion," Conference Proceeding of the $38^{\text {th }}$ ASEE Midwest Section Meeting, Sept. 10-12, Rolla, MO, 9 pages

4. Yee, D., "Introduction: recognizing diversity, moving toward cultural competence." Generations (San Francisco, Calif.), 26(3), 2002

5. McGown, J. (2002). Multicultural competency development: preparing students to live and work in a diverse world. Retrieved May 082003 http://www.ksu.edu/catl/tilford/Competencies.htm.

Beverlee Kissick earned three degrees from Kansas State University at Manhattan, Kansas: a B.S. in Sociology, MS in Curriculum and Instruction, and a Ph.D. in Educational Technology Library/Media. Beverlee is a Professor and Director of Libraries at Kansas State University at Salina where she has taught sociology. Beverlee taught at Virginia Commonwealth University, Richmond, Virginia, Fort Hays State University, Hays, Kansas, and in Kansas public schools. Kissick chaired the diversity committee at KSU at Salina for three years and has served on the President's Council on Multicultural Affairs and the Tilford Group at Kansas State University at Manhattan. Beverlee is known for her presentations on Practical Humanities.

Saeed Khan is an Assistant Professor with the Electronic and Computer Engineering Technology program at Kansas State University at Salina. Dr. Khan received his Ph.D. and M.S. degrees in Electrical Engineering from the University of Connecticut, in 1989 and 1994 respectively. He received his B.S. in Electrical Engineering from Bangladesh University of Engineering and Technology, Dhaka, Bangladesh in 1984. Khan, who joined KSU in 1998, teaches courses in telecommunications and digital systems. His research interests and areas of expertise include antennas and propagation, novel materials for microwave application, and electromagnetic scattering. Dr. Khan chairs the diversity committee at the College of Technology and Aviation, serves as a member of the President's Council on Multicultural Affairs, and is the college representative for the Tilford Group, a research and development group charged with creating a multicultural curriculum model. 